\title{
Quantification of selected steroid hormones (17b-Estradiol and 17a-Ethynylestradiol) in wastewater treatment plants in Klang Valley (Malaysia)
}

\begin{abstract}
Steroid estrogens, such as $17 \beta$-estradiol (E2) and 17 $\alpha$-ethynylestradiol (EE2) are potent and were categorized as "Watch List" in Directive 2013/39/EU because of their potential risks to aquatic environment. Commercialized enzyme-linked immunosorbent assay (ELISA) kits have been used to quantify steroid estrogens in wastewater samples due to their simplicity, rapid, cost-effectiveness, and validated assays. Hence, this study aims to determine the occurrence and removal of steroid hormones in Malaysian wastewater treatment plants (WWTPs) by ELISA, to identify the association of removal efficiency (E2 and EE2) with respect to WWTPs operating conditions, and to assess the potential risks of steroid estrogens to aquatic environment and human. Results showed E2 concentration ranged from $88.2 \pm 7.0$ $\mathrm{ng} / \mathrm{L}$ to $93.9 \pm 6.9 \mathrm{ng} / \mathrm{L}$ in influent and $35.1 \pm 17.3 \mathrm{ng} / \mathrm{L}$ to $85.2 \pm 7.6 \mathrm{ng} / \mathrm{L}$ in effluent, with removal of 6.4\%-63.0\%. The EE2 concentration ranged from $0.2 \pm 0.2 \mathrm{ng} / \mathrm{L}$ to $4.9 \pm 6.3 \mathrm{ng} / \mathrm{L}$ in influent and $0.02 \pm 0.03 \mathrm{ng} / \mathrm{L}$ to $1.0 \pm 0.8 \mathrm{ng} / \mathrm{L}$ in effluent, with removal of $28.3-99.3 \%$.

There is a correlation between EE2 removal with total suspended solid (TSS) and oxidation reduction potential (ORP), and was statistically significant. Despite the calculated estrogenic activity for E2 and EE2 was relatively high, dilution effects could lower estrogenic response to aquatic environment. Besides, these six selected WWTPs have cumulative RQ values below the allowable limit, except WWTP 1. Relatively high precipitation (129-218 mm) could further dilute estrogens concentration in the receiving river. These outputs can be used as quantitative information for evaluating the occurrence and removal of steroid estrogens in Malaysian WWTPs.
\end{abstract}

Keyword: $17 \alpha$-ethynylestradiol; $17 \beta$-estradiol; Enzyme-linked immunosorbent assay; Potential risks; Wastewater treatment plant 